\title{
Pheno- and Genotyping of Staphylococcus aureus Isolates of Sheep Origin
}

\author{
Jana Mašlanková, Ivana Pilipčincová, L’udmila Tkáčiková \\ Department of Microbiology and Immunology, University of Veterinary Medicine, Košice, Slovak Republic
}

Received September 8, 2008

Accepted November 12, 2008

\begin{abstract}
The aim of the study was to determine the prevalence of genes encoding virulence factors in Staphylococcus aureus strains isolated from raw sheep milk, sheep cheese and Bryndza cheese. Genes encoding staphylococcal enterotoxin ( $s e a, s e b, s e c$, sed and see), toxic shock syndrome toxin-1 (tst), exfoliative toxins (eta and etb) and collagen-binding protein (cna) were detected. In a total of $79 \mathrm{~S}$. aureus isolates all assessed toxins encoding genes were found, except for see, eta and $e t b$. Overall, $75.9 \%$ of $S$. aureus isolates were found to be positive for one or more toxin genes. The sec gene was found most frequently (24.1\%), followed by $t s t(22.8 \%)$, seb (13.9\%), sed $(10.1 \%)$ and sea $(5.1 \%)$. The cna gene was detected in $55.7 \%$ of $S$. aureus isolates. Based on tandem repeats in coa gene, five coa types were observed, further divided into 16 subtypes based on their RFLP pattern. Similarly tandem repeats in spa gene divided $S$. aureus isolates into 7 types. In the parallel antibiotic resistance study, $69.6 \%$ isolates were resistant to at least one of the 11 tested antibiotics. The pheno- and genotyping of $S$. aureus isolates of sheep origin presented in this work update the epidemiological data in Slovakia.
\end{abstract}

Milk, cheese, sheep-bacteria, toxins, coa and spa genotyping, antimicrobial resistance

Staphylococcus aureus, the most important aetiological agent of contagious bovine and ovine mastitis, has attracted attention by its presence in the infected udder and by environmental contamination of milk during handling and processing (Scherrer et al. 2004; Jorgensen et al. 2005). Epidemiological survey is therefore important to prevent the spread of $S$. aureus.

The virulence of $S$. aureus has been postulated to depend on the expression of a wide range of cell wall-associated and secreted molecules that are believed to promote colonization of host tissues and evasion of the host immune response (Foster and Hook 1998; Dinges et al. 2000). Adherence to host tissue is the first critical step required to initiate infection and is mediated by collagen-binding protein (Cna) and adhesins of the microbial surface components, recognizing adhesive matrix molecules (MSCRAMM) (Foster and Hook 1998). S. aureus also produces a wide variety of extracellular toxins of which the most important are staphylococcal enterotoxins (SEs), toxic shock syndrome toxin-1 (TSST-1), and exfoliative toxins (ET). Each of these toxins has a potent effect on cells of the immune system (Dinges et al. 2000). Some SEs are potent emetics (Boerema et al. 2006). TSST-1 is unique in its ability to cross mucosal surfaces and to develop life-threatening toxic shock syndrome (Llewelyn and Cohen 2002; Proft and Fraser 2003).

Because $S$. aureus is a common pathogen for humans and animals, many studies were orientated towards staphylococcal antibiotic resistance (Lyon and Skurray 1987; Werckenthin et al. 2001; Strommenger et al. 2003; Normanno et al. 2007; Wang et al. 2008). In human medicine, antimicrobial multiresistance is frequently encountered and methicillin-resistant $S$. aureus strains (MRSA) belong to the most life threatening nosocomial bacteria. In veterinary medicine, however, MRSA and multiresistant $S$. aureus strains are only reported occasionally (Werckenthin et al. 2001; Normanno et al. 2007).

Little is known about the occurrence of virulence factors in ovine $S$. aureus strains. The

Address for correspondence:

Doc. MVDr. Ludmila Tkáčiková, Ph.D.

Department of Microbiology and Immunology

University of Veterinary Medicine

Komenského 73, 94181 Košice

Slovakia

Phone: +421915984603

E-mail: tkacikova@uvm.sk

http://www.vfu.cz/acta-vet/actavet.htm 
objective of this study was pheno- and genotyping of ovine $S$. aureus strains isolated from sheep milk, sheep cheese and Bryndza cheese (typical Slovak sheep cheese) samples from Slovakia.

\section{Materials and Methods}

Bacterial strains and culture media

During the years 2004 - 2007, raw sheep milk and cheese samples were screened for staphylococcal contamination by classical microbiological examination (ISO 6888-1). Based on colony morphology (growth on Baird-Parker agar) and coagulase production 79 possible $S$. aureus isolates (49 raw sheep milk, 24 sheep cheese and 6 Bryndza cheese) were selected for further genospecies confirmation and geno-phenotyping. Reference strains used in PCR based assays were: S. aureus CCM 2353 (cna gene), S. aureus CCM 7056 (eta and etb genes), S. aureus CCM 5756 (sea gene), S. aureus CCM 5984 (sec gene) and S. aureus CCM 5972 (see gene) (Czech Collection of Microorganisms, Brno, Czech Republic). Working cultures of all strains were prepared by inoculation from frozen glycerol stocks into brain heart infusion (BHI) broth (Oxoid, Basingstoke, Hampshire, UK) followed by incubation at $37^{\circ} \mathrm{C}$ for $16-18 \mathrm{~h}$.

Antibiotic susceptibility testing - disc diffusion assays

Discs (Oxoid) with oxacillin (OXA), chloramphenicol (CMP), tetracycline (TET), erythromycin (ERY), gentamycin (GEN), kanamycin (KAN), streptomycin (STR), vankomycin (VAN), linkomycin (LCM), clindamycin (CLI) and spiramycin (SPI) were added onto $S$. aureus inoculated Mueller-Hinton agar plates (Oxoid) (Table 6). The zone of inhibition was determined after $24 \mathrm{~h}$ of incubation at $37^{\circ} \mathrm{C}$. The zone size was interpreted according to the recommendations of the CLSI criteria (CLSI, 2004).

Nucleic acid amplification - PCR: Nucleic acid amplification was performed on S. aureus genomic DNA isolated according to (Hein et al. 2005). PCRs were performed either in multiplex (set A, set B and set C) (Sharma et al. 2000) or as a single reaction (mecA, cna, spa and coa) (Table 1). Cycling conditions for each type of PCR were according to the authors depicted in Table 1. Amplified products were detected in $1.5 \%$ agarose gel.

DNA restriction endonuclease analysis of the PCR-amplified coagulase gene

For coagulase genotyping, a PCR-RFLP analysis of isolates was performed according to the method of Hookey et al. (1998). Ten $\mu$ l of PCR product was digested with $2 \mathrm{U}$ of HaeIII (Fermentas, Vilnius, Lithuania) at $37^{\circ} \mathrm{C}$ overnight. After restriction the samples were analysed by electrophoresis in $2 \%$ agarose gel.

\section{Results and Discussion}

Specific gene amplification of $16 \mathrm{~S}$ rRNA and S. aureus (Martineau et al. 1998) confirmed $79 \mathrm{~S}$. aureus isolates already selected based on the microbiological criteria like colony characterization and coagulase production.

In $79 \mathrm{~S}$. aureus isolates all the assessed toxin genes were found, except for see, eta and $e t b$. Overall, $75.9 \% \mathrm{~S}$. aureus isolates were found to be positive for one or more toxin genes. The sec gene was found most frequently $(24.1 \%)$, followed by $t s t(22.8 \%)$, seb $(13.9 \%)$, sed $(10.1 \%)$ and finally, sea $(5.1 \%)$. The tst gene was the only gene present in all types of isolates (Table 2).

The presence of sea, seb, sed, see and tst genes in $S$. aureus strains associated with bovine mastitis has been described earlier (Akineden et al. 2001; Stephan et al. 2001; Scherrer et al. 2004; Zschock et al. 2004; Morandi et al. 2007). Of the staphylococcal enterotoxin encoding genes, the $\mathrm{sec}$ gene has been reported to have the highest frequency in bovine as well as ovine isolates (S cherrer et al. 2004). We obtained similar results, where out of 42 enterotoxin positive strains, $19(45.2 \%)$ were $\sec$ positive.

The presence of more than one toxin genes was found in $15.2 \% \mathrm{~S}$. aureus isolates. In our study, from all 18 tst positive isolates, $6(33.6 \%)$ were also positive for the $\mathrm{sec}$ gene. The strains positive for sec-tst were isolated mostly from sheep cheese; only one with the sebsec-tst gene combination was found in sheep milk isolate (Table 3).

A high co-occurrence between sec and tst has also been reported for bovine $S$. aureus strains (Akineden et al. 2001; Stephan et al. 2001; Zschock et al. 2004). Smyth et al. (2005) published a high prevalence $(19.2 \%, 46.2 \%$ and $60.9 \%)$ of the tst gene in bovine, goat and sheep isolates, respectively. In the present study the tst gene was the only gene found in isolates from Bryndza cheese. These isolates did not show any double presence of toxin genes. Whether TSST-1 plays a role in the pathogenesis of mastitis is still unknown. 


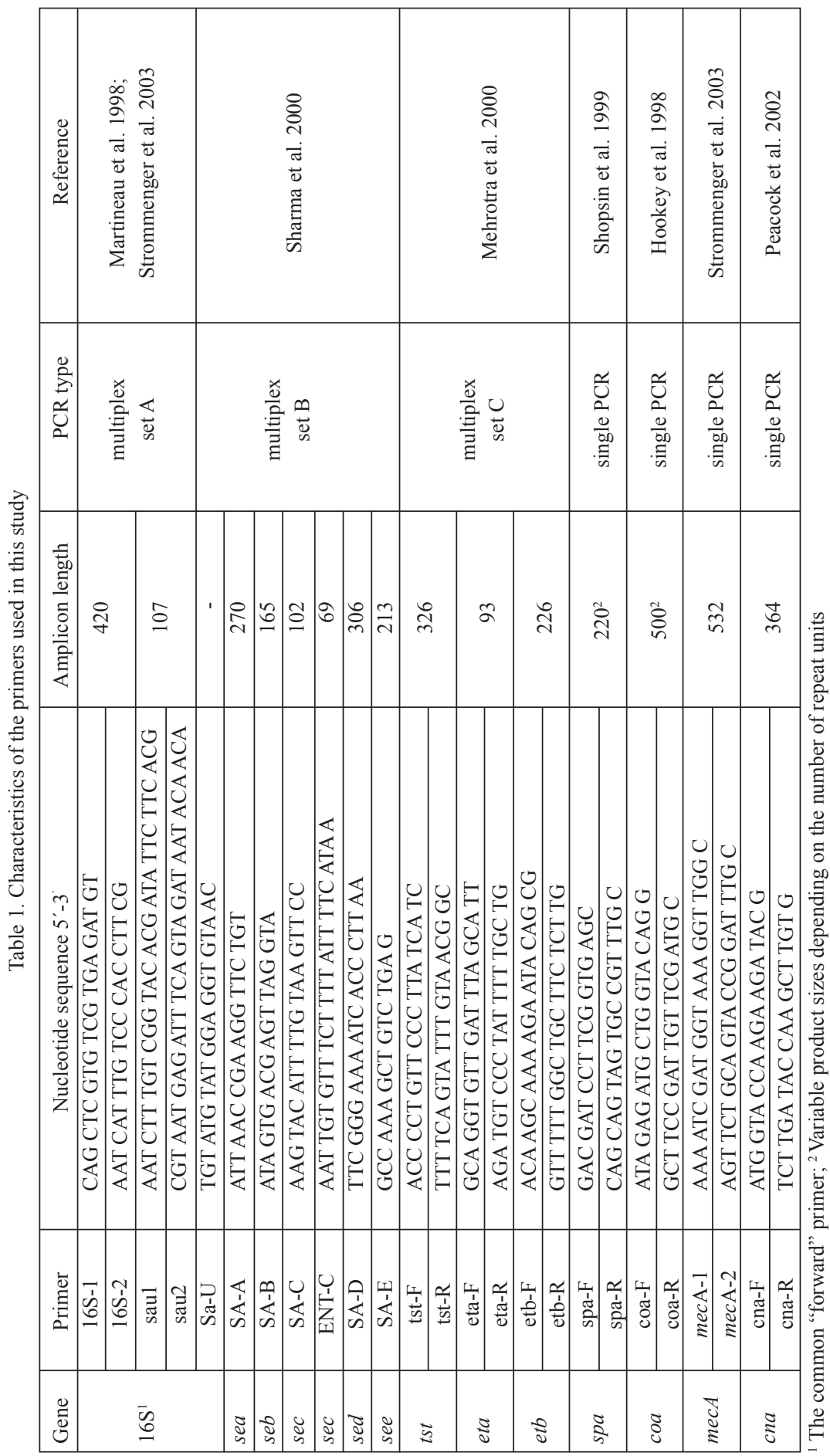


Table 2. Distribution of toxin encoding genes among $S$. aureus isolates

\begin{tabular}{|l|c|c|c|c|c|c|c|c|c|}
\hline & \multicolumn{7}{|c|}{ Toxin gene } & \multirow{2}{*}{ Total } \\
\cline { 2 - 10 } & sea & seb & sec & sed & see & tst & eta & etb & \\
\hline Sheep milk $(\mathrm{n}=49)$ & $4(8.2)$ & $10(20.4)$ & $12(24.5)$ & $6(12.2)$ & - & $6(12.2)$ & - & - & $38(77.6)$ \\
\hline Sheep cheese $(\mathrm{n}=24)$ & - & $1(4.2)$ & $7(29.2)$ & $2(8.3)$ & - & $10(41.7)$ & - & - & $20(83.3)$ \\
\hline Bryndza cheese $(\mathrm{n}=6)$ & - & - & - & - & - & $2(33.3)$ & - & - & $2(33.3)$ \\
\hline Total $(\mathrm{n}=79)$ & $4(5.1)$ & $11(13.9)$ & $19(24.1)$ & $8(10.1)$ & - & $18(22.8)$ & - & - & $60(75.9)$ \\
\hline
\end{tabular}

Numbers in parentheses are percentages

Table 3. Distribution of $S$. aureus isolates with different combination of toxin genes

\begin{tabular}{|l|c|c|c|c|c|c|c|c|}
\hline & \multicolumn{9}{|c|}{ Toxin genes } \\
\cline { 2 - 10 } & sea, seb & seb, sec & sec, sed & sec, tst & sed, tst & seb, sec, tst & seb, sed, tst & sec, sed, tst \\
\hline Sheep milk $(\mathrm{n}=49)$ & $1(2.0)$ & $2(4.1)$ & - & - & $1(2.0)$ & $1(2.0)$ & $1(2.0)$ & - \\
\hline Sheep cheese $(\mathrm{n}=24)$ & - & - & $1(4.2)$ & $4(16.7)$ & - & - & - & $1(4.2)$ \\
\hline Bryndza cheese $(\mathrm{n}=6)$ & - & - & - & - & - & - & - & - \\
\hline Total $(\mathrm{n}=79)$ & $1(1.3)$ & $2(2.5)$ & $1(1.3)$ & $4(5.1)$ & $1(1.3)$ & $1(1.3)$ & $1(1.3)$ & $1(1.3)$ \\
\hline
\end{tabular}

Numbers in parentheses are percentages

TSST-1 and staphylococcal enterotoxins may act as superantigens for cells of the bovine immune system and may potentially contribute to the pathological mechanisms of bovine mastitis. Some other authors also described high co-occurrence of $\mathrm{sec}$ and tst genes in sheep (Orden et al. 1992; Hayakawa et al. 2000; Scherrer et al. 2004). This data suggest that the sec gene may be present on a pathogenicity island together with the $t s t$ gene (Fitzgerald et al. 2001).

Many authors studied the production of exfoliative toxins among $S$. aureus isolates from bovine mastitis and have reported a rare prevalence of these toxins (Hayakawa et al. 2000; Akineden et al. 2001; Larsen et al. 2002; Endo et al. 2003). The present study confirms that these genes are rare in $S$. aureus isolates from sheep; eta and etb genes were not found in any of our isolates.

In this study we found a high prevalence of the collagen binding protein ( $c n a)$ gene $(55.7 \%)$. The gene was found most frequently in isolates from Bryndza cheese $(83.3 \%)$, followed by sheep milk (55.1\%) and sheep cheese (50\%). The collagen binding protein mediates bacterial adherence to collagen substrates and collagenous tissue and can therefore be a virulence factor of $S$. aureus (Peacock et al. 2002; Zong et al. 2005). The cna gene is usually not present in $S$. aureus strains (Elasri et al. 2002).

Production of coagulase encoding by the coa gene is an important phenotypic feature used worldwide to identify S. aureus (Sutra and Poutrel 1994; Panizzi et al. 2004). In the present study five different amplicons of the coa gene with sizes ranging from 500-820 bp were found: type A (500 bp with 4 tandem repeats; 4TR), type B (580 bp, 5TR), type C (660 bp, 6TR), type D (740 bp, 7TR) and type E (820 bp, 8TR). Only type D (7TRs) was present in all isolates. 6TR and 7TR together account for the majority of the isolates $(63 \%)$ (Table 4).

The use of PCR-RFLP for analysis of the coa gene allowed a more detailed characterization of the $S$. aureus isolates. In this study the highest polymorphism was recorded in type C, with 4 or 5 subtypes in sheep milk and sheep cheese isolates, respectively, and in type D with 4, 2 or 1 subtype in sheep milk, sheep cheese and Bryndza cheese isolates, respectively. Some coa types or subtypes were recorded only in $S$. aureus isolates from sheep cheese (B, E and C5-C7) or sheep milk (C3, C4, D3 and D4) (Table 4).

Katsuda et al. (2005) and other authors (Lange et al. 1999; Schlegelová et al. 2003) described a number of tandem repeats in the coa gene ranging from 3 to 9 and bovine 
Table 4. Polymorphism in coa gene of $S$. aureus isolates

\begin{tabular}{|c|c|c|c|c|c|}
\hline $\begin{array}{l}\text { PCR product } \\
\text { (bp) }\end{array}$ & $\begin{array}{c}\text { Type and } \\
\text { no. of TR } / \text { subtype }^{\mathrm{b}}\end{array}$ & $\begin{array}{l}\text { Sheep milk } \\
(\mathrm{n}=49)\end{array}$ & $\begin{array}{l}\text { Sheep cheese } \\
\qquad(\mathrm{n}=24)\end{array}$ & $\begin{array}{l}\text { Bryndza cheese } \\
\qquad(n=6)\end{array}$ & $\begin{array}{c}\text { Total } \\
(\mathrm{n}=79)\end{array}$ \\
\hline \multirow{3}{*}{500} & $\mathrm{~A} / 4 \mathrm{TR}$ & $10(20.4)$ & $2(8.3)$ & - & $12(15.2)$ \\
\hline & A1 & $1(2.0)$ & $1(4.2)$ & - & $2(2.5)$ \\
\hline & A2 & $9(18.4)$ & $1(4.2)$ & - & $10(12.7)$ \\
\hline \multirow{2}{*}{580} & $\mathrm{~B} / 5 \mathrm{TR}$ & - & $1(4.2)$ & - & $1(1.3)$ \\
\hline & B1 & - & $1(4.2)$ & - & $1(1.3)$ \\
\hline \multirow{8}{*}{660} & $\mathrm{C} / 6 \mathrm{TR}$ & $19(38.8)$ & $7(29.2)$ & - & $26(32.1)$ \\
\hline & $\mathrm{C} 1$ & $6(12.2)$ & $2(8.3)$ & - & $8(10.1)$ \\
\hline & $\mathrm{C} 2$ & $5(10.2)$ & $1(4.2)$ & - & $6(7.6)$ \\
\hline & C3 & $3(6.1)$ & - & - & $3(3.8)$ \\
\hline & $\mathrm{C} 4$ & $5(10.2)$ & - & - & $5(6.3)$ \\
\hline & $\mathrm{C5}$ & - & $1(4.2)$ & - & $1(1.3)$ \\
\hline & C6 & - & $1(4.2)$ & - & $1(1.3)$ \\
\hline & $\mathrm{C} 7$ & - & $2(8.3)$ & - & $2(2.5)$ \\
\hline \multirow{5}{*}{740} & $\mathrm{D} / 7 \mathrm{TR}$ & $20(40.8)$ & $11(45.8)$ & $6(100)$ & $37(44.3)$ \\
\hline & D1 & $13(26.5)$ & $10(41.6)$ & $6(100)$ & $29(36.7)$ \\
\hline & D2 & $3(6.1)$ & $1(4.2)$ & - & $4(5.1)$ \\
\hline & D3 & $1(2.0)$ & - & - & $1(1.3)$ \\
\hline & D4 & $3(6.1)$ & - & - & $3(3.8)$ \\
\hline \multirow{3}{*}{820} & $\mathrm{E} / 8 \mathrm{TR}$ & - & $3(12.5)$ & - & $3(3.8)$ \\
\hline & E1 & - & $2(8.3)$ & - & $2(2.5)$ \\
\hline & E2 & - & $1(4.2)$ & - & $1(1.3)$ \\
\hline
\end{tabular}

a Tandem repeats

${ }^{\mathrm{b}}$ Subtypes determined by PCR-RFLP

Numbers in parentheses are percentages

S. aureus strains mostly showing five tandem repeats. Scherrer et al. (2004) studied polymorphisms in the coa gene of $S$. aureus isolates from sheep and goat milk. They report an $80.6 \%$ prevalence of eight tandem repeats in sheep milk samples. In sheep isolates we only found one with 5TR. This could indicate a connection between mastitis and 5TR in the coa gene of $S$. aureus isolates, as our isolates were not specifically from animals with mastitis.

The detection of variation in the $\mathrm{X}$ region of the spa gene is also used for the epidemiological study of $S$. aureus. Amplicons of the spa gene with different sizes ranging from $224-392 \mathrm{bp}$ were observed in $82.4 \%$ S. aureus isolates (Table 5). Based on the size of the corresponding amplicons, 4 to 11 highly polymorphic tandem repeats (TR, $24 \mathrm{bp}$ long) (Frenay et al. 1994; Shopsin et al. 1999) were supposed to be present in this X region. In the present study only two spa types (5TR and 6TR) were found in all isolates. Some spa

Table 5. Polymorphism in numbers of tandem repeats in X region of spa gene of S. aureus isolates

\begin{tabular}{|l|c|c|c|c|c|c|c|c|}
\hline \multirow{4}{*}{$\begin{array}{l}\text { Sheep milk }(\mathrm{n}=49) \\
\text { Sheep cheese }(\mathrm{n}=24)\end{array}$} & \multicolumn{7}{|c|}{ Amplicon size (bp) / Number of tandem repeats in X region of spa gene } \\
\cline { 2 - 9 } $\begin{array}{l}\text { Bryndza cheese }(\mathrm{n}=6) \\
\text { Total }(\mathrm{n}=79)\end{array}$ & - & $8(33.3)$ & $5(20.8)$ & - & $1(4.2)$ & $7(29.2)$ & - & $21(87.5)$ \\
\cline { 2 - 10 } & - & $1(16.7)$ & $5(83.3)$ & - & - & - & - & $6(100)$ \\
\cline { 2 - 9 } & $10(12.7)$ & $14(17.7)$ & $12(15.2)$ & $6(7.6)$ & $1(1.3)$ & $16(20.3)$ & $6(7.6)$ & $65(82.4)$ \\
\hline
\end{tabular}

Numbers in parentheses are percentages 
types were observed only in isolates from sheep milk (4TR, 7TR and 11TR) or only from sheep cheese (9TR) (Table 5).

Several authors studied polymorphisms in the X region of the spa gene of bovine $S$. aureus. Lange et al. (1999) recorded the presence of 5TR to 12TR (except 10TR) with a predominance of 6TR. Stephan et al. (2001) recorded the presence of 2TR, 6TR, 10TR and 11TR with a predominance of 6TR and Kalorey et al. (2007) recorded the presence of 4TR, 5TR, and 8TR with a predominance for 4TR. To the best of our knowledge, this publication describes the variation of the X-region of the spa gene in isolates from sheep milk and sheep cheese for the first time.

Over the last few decades, there has been an enormous increase and emergence of $S$. aureus strains resistant to the antibiotic methicillin (MRSA strains). MRSA is known to be one of the most prevalent nosocomial pathogens throughout the world and to be capable of causing a wide range of hospital-linked infections (Mehrotra et al. 2000). In the present study, methicillin resistance was not present in any of the tested $S$. aureus isolates. Pengov and Ceru (2003) also recorded a low prevalence of resistance to penicillin and ampicillin in ovine isolates. This can be explained by the reduction of the use of b-lactam antibiotics for treatment of sheep; the presence of a different population of S. aureus genotypes in the ovine mammary gland is likely to be partly responsible for this as well.

In the present study all staphylococcal isolates were susceptible to oxacillin, tetracycline and gentamycin. A low level of resistance to chloramphenicol, kanamycin and streptomycin was recorded in isolates from sheep milk only. Resistance to vankomycin was recorded only in one isolate from sheep cheese. A high prevalence of resistance to linkomycin, spiramycin and to clindamycin was recorded (Table 6). The prevalence of resistance was higher in isolates from sheep milk than in isolates from sheep cheese and from Bryndza cheese. We also found multiresistant S. aureus isolates. Multiresistance to CMP-ERYKAN-STR-LCM-SPI, ERY-VAN-LCM-CLI-SPI or LCM-CLI-SPI was recorded in one staphylococcal isolate from sheep milk, sheep cheese and Bryndza cheese, respectively. Resistance to LCM-SPI was recorded in 10 isolates; resistance to LCM-CLI was recorded in 4 isolates.

Table 6. Distribution of antibiotic resistance among of $S$. aureus isolates

\begin{tabular}{|l|c|c|c|c|c|c|c|c|c|c|c|}
\hline & \multicolumn{10}{|c|}{ Antibiotics; Disc content } \\
\cline { 2 - 14 } & OXA & TET & CMP & GEN & KAN & STR & VAN & LCM & CLI & SPI & ERY \\
\cline { 2 - 13 } & $5 \mu \mathrm{g}$ & $30 \mu \mathrm{g}$ & $30 \mu \mathrm{g}$ & $10 \mu \mathrm{g}$ & $30 \mu \mathrm{g}$ & $10 \mu \mathrm{g}$ & $30 \mu \mathrm{g}$ & $10 \mu \mathrm{g}$ & $10 \mu \mathrm{g}$ & $20 \mu \mathrm{g}$ & $15 \mu \mathrm{g}$ \\
\hline Sheep milk $(\mathrm{n}=49)$ & - & - & $2(4.1)$ & - & $1(2.0)$ & $1(2.0)$ & - & $20(40.8)$ & $2(4.1)$ & $6(12.2)$ & $1(2.0)$ \\
\hline Sheep cheese $(\mathrm{n}=24)$ & - & - & - & - & - & - & $1(4.2)$ & $8(33.3)$ & $2(8.3)$ & $3(12.5)$ & $1(4.2)$ \\
\hline Bryndza cheese (n=6) & - & - & - & - & - & - & - & $3(50.0)$ & $2(33.3)$ & $2(33.3)$ & - \\
\hline Total (n=79) & - & - & $2(2.5)$ & - & $1(1.3)$ & $1(1.3)$ & $1(1.3)$ & $31(39.2)$ & $6(7.6)$ & $11(13.9)$ & $2(2.5)$ \\
\hline
\end{tabular}

OXA, oxacillin; TET, tetracycline; CMP, chloramphenicol; GEN, gentamicin; KAN, kanamycin; STR, streptomycin; VAN, vankomycin; LCM, lincomycin; CLI, clindamycin; SPI, spiramycin; ERY, erythromycin Numbers in parentheses are percentages

The reason for a high prevalence of resistance to linkomycin, spiramycin and clindamycin in our study is probably the use of these antibiotics for treatment of sheep mastitis. Wang at al. (2008) also reported a considerably higher resistance to lincosamides (linkomycin and clindamycin) or macrolides (erythromycin and spiramycin) in S. aureus strains isolated from bovine mastitis.

To our knowledge, this is the first study providing comprehensive characterisation data of $S$. aureus strains originating from sheep milk and sheep cheese samples in Slovakia. 


\section{Feno- a genotypizácia ovčích izolátov Staphylococcus aureus}

Ciel'om tejto práce bolo stanovit' prevalenciu génov kódujúcich faktory virulencie v izolátoch Staphylococcus aureus získaných zo surového ovčieho mlieka, ovčieho syra a bryndze. Boli sledované gény kódujúce stafylokokové enterotoxíny (sea, seb, sec, sed a see), toxín syndrómu toxického šoku-1 (tst), exfoliatívne toxíny (eta a etb) a proteín viažuci kolagén (cna). Vo všetkých 79 S. aureus izolátoch boli nájdene vyššie spomenuté gény s výnimkou see, eta a etb génov. Celkovo bolo $75,9 \% \mathrm{~S}$. aureus izolátov pozitívnych pre jeden a viac toxínových génov. Najčastejšie bol nájdený $s e c$ gén $(24,1 \%)$, potom tst $(22,8 \%)$, seb $(13,9 \%)$, sed $(10,1 \%)$ a sea $(5,1 \%)$ gény. $55,7 \%$ S. aureus izolátov malo cna gén. Na základe analýzy tandemových repetícií v coa géne bolo nájdených 5 coa typov, ktoré boli na základe RFLP analýzy rozdelené do 16 podtypov. Podobne analýza počtu tandemových repetícií v spa géne rozdelila izoláty $S$. aureus na 7 typov. V súbežnej štúdii antibiotikorezistencie bolo zistené, že 69,6 \% izolátov bolo rezistentných aspoň na jedno z 11 testovaných antibiotík. Feno- a genotypizácia ovčích izolátov $S$. aureus prezentovaná v tejto práci aktualizuje epidemiologické údaje na Slovensku.

\section{References}

Akineden O, Annemuller C, Hassan AA, Lammler C, Wolter W, Zschock M 2001: Toxin genes and other characteristics of Staphylococcus aureus isolates from milk of cows with mastitis. Clin Diagn Lab Immunol 8: $959-964$

Boerema JA, Clemens R, Brightwell G 2006: Evaluation of molecular methods to determine enterotoxigenic status and molecular genotype of bovine, ovine, human and food isolates of Staphylococcus aureus. Int J Food Microbiol 107: 192-201

CLSI 2004: Performance standards for antimicrobial disc and dilution susceptibility tests for bacteria isolated from animals. Informational supplement. CLSI document M31-S1 [ISBN1-56238-534-8]. CSLI 940, West Valley Road, Suite 1400, Wayne, Pennsylvania, 190987-1898 USA.

Dinges MM, Orwin PM, Schlievert PM 2000: Exotoxins of Staphylococcus aureus. Clin Microbiol Rev 13: 1634

Elasri MO, Thomas JR, Skinner RA, Blevins JS, Beenken KE, Nelson CL, Smeltzer MS 2002: Staphylococcus aureus collagen adhesin contributes to the pathogenesis of osteomyelitis. Bone 30: 275-280

Endo Y, Yamada T, Matsunaga K, Hayakawa Y, Kaidoh T, Takeuchi S 2003: Phage conversion of exfoliative toxin A in Staphylococcus aureus isolated from cows with mastitis. Vet Microbiol 96: 81-90

Fitzgerald JR, Monday SR, Foster TJ, Bohach GA, Hartigan PJ, Meaney WJ, Smyth CJ 2001: Characterization of a putative pathogenicity island from bovine Staphylococcus aureus encoding multiple superantigens. J Bacteriol 183: 63-70

Foster TJ, Hook M 1998: Surface protein adhesins of Staphylococcus aureus. Trends Microbiol 6: 484-488

Frenay HM, Theelen JP, Schouls LM, Vandenbroucke-Grauls CM, Verhoef J, Van Leeuwen WJ, Mooi FR 1994: Discrimination of epidemic and nonepidemic methicillin-resistant Staphylococcus aureus strains on the basis of protein A gene polymorphism. J Clin Microbiol 32: 846-847

Hayakawa Y, Akagi M, Hayashi M, Shimano T, Komae H, Funaki O, Kaidoh T, Takeuchi S 2000: Antibody response to toxic shock syndrome toxin-1 of Staphylococcus aureus in dairy cows. Vet Microbiol 72: 321327

Hein I, Jorgensen HJ, Loncarevic S, Wagner M 2005: Quantification of Staphylococcus aureus in unpasteurised bovine and caprine milk by real-time PCR. Res Microbiol 156: 554-563

Hookey JV, Richardson JF, Cookson BD 1998: Molecular typing of Staphylococcus aureus based on PCR restriction fragment length polymorphism and DNA sequence analysis of the coagulase gene. J Clin Microbiol 36: $1083-1089$

ISO 6888-1 1999: Horizontal method for the enumeration of coagulase-positive staphylococci.

Jorgensen HJ, Mork T, Caugant DA, Kearns A, Rorvik LM 2005: Genetic variation among Staphylococcus aureus strains from Norwegian bulk milk. Appl Environ Microbiol 71: 8352-8361

Kalorey DR, Shanmugam Y, Kurkure NV, Chousalkar KK, Barbuddhe SB 2007: PCR-based detection of genes encoding virulence determinants in Staphylococcus aureus from bovine subclinical mastitis cases. J Vet Sci 8: $151-154$

Katsuda K, Hata E, Kobayashi H, Kohmoto M, Kawashima K, Tsunemitsu H, Eguchi M 2005: Molecular typing of Staphylococcus aureus isolated from bovine mastitic milk on the basis of toxin genes and coagulase gene polymorphisms. Vet Microbiol 105: 301-305

Lange C, Cardoso M, Senczek D, Schwarz S 1999: Molecular subtyping of Staphylococcus aureus isolates from cases of bovine mastitis in Brazil. Vet Microbiol 67: 127-141 
Larsen HD, Aarestrup FM, Jensen NE 2002: Geographical variation in the presence of genes encoding superantigenic exotoxins and beta-hemolysin among Staphylococcus aureus isolated from bovine mastitis in Europe and USA. Vet Microbiol 85: 61-67

Llewelyn M, Cohen J 2002: Superantigens: microbial agents that corrupt immunity. Lancet Infect Dis 2: 156-162

Lyon BR, Skurray R 1987: Antimicrobial resistance of Staphylococcus aureus: genetic basis. Microbiol Rev 51: $88-134$

Martineau F, Picard FJ, Roy PH, Ouellette M, Bergeron MG 1998: Species-specific and ubiquitous-DNA-based assays for rapid identification of Staphylococcus aureus. J Clin Microbiol 36: 618-623

Mehrotra M, Wang G, Johnson WM 2000: Multiplex PCR for detection of genes for Staphylococcus aureus enterotoxins, exfoliative toxins, toxic shock syndrome toxin 1, and methicillin resistance. J Clin Microbiol 38: 1032-1035

Morandi S, Brasca M, Lodi R, Cremonesi P, Castiglioni B 2007: Detection of classical enterotoxins and identification of enterotoxin genes in Staphylococcus aureus from milk and dairy products. Vet Microbiol 124: $66-72$

Normanno G, La Salandra G, Dambrosio A, Quaglia NC, Corrente M, Parisi A, Santagada G, Firinu A, Crisetti E, Celano GV 2007: Occurrence, characterization and antimicrobial resistance of enterotoxigenic Staphylococcus aureus isolated from meat and dairy products. Int J Food Microbiol 115: 290-296

Orden JA, Cid D, Blanco ME, Ruiz Santa Quiteria JA, Gomez-Lucia E, De la Fuente R 1992: Enterotoxin and toxic shock syndrome toxin-one production by staphylococci isolated from mastitis in sheep. APMIS 100: $132-134$

Panizzi P, Friedrich R, Fuentes-Prior P, Bode W, Bock PE 2004: The staphylocoagulase family of zymogen activator and adhesion proteins. Cell Mol Life Sci 61: 2793-2798

Peacock SJ, Moore CE, Justice A, Kantzanou M, Story L, Mackie K, O’Neill G, Day NP 2002: Virulent combinations of adhesin and toxin genes in natural populations of Staphylococcus aureus. Infect Immun 70: 4987-4996

Pengov A, Ceru S 2003: Antimicrobial drug susceptibility of Staphylococcus aureus strains isolated from bovine and ovine mammary glands. J Dairy Sci 86: 3157-3163

Proft T, Fraser JD 2003: Bacterial superantigens. Clin Exp Immunol 133: 299-306

Sharma NK, Rees CE, Dodd CE 2000: Development of a single-reaction multiplex PCR toxin typing assay for Staphylococcus aureus strains. Appl Environ Microbiol 66: 1347-1353

Shopsin B, Gomez M, Montgomery SO, Smith DH, Waddington M, Dodge DE, Bost DA, Riehman M, Naidich S, Kreiswirth BN 1999: Evaluation of protein A gene polymorphic region DNA sequencing for typing of Staphylococcus aureus strains. J Clin Microbiol 37: 3556-63

Scherrer D, Corti S, Muehlherr JE, Zweifel C, Stephan R 2004: Phenotypic and genotypic characteristics of Staphylococcus aureus isolates from raw bulk-tank milk samples of goats and sheep. Vet Microbiol 101: 101-107

Schlegelová J, Dendis M, Benedik J, Babák V, Ryšánek D 2003: Staphylococcus aureus isolates from dairy cows and humans on a farm differ in coagulase genotype. Vet Microbiol 92: 327-334

Smyth DS, Hartigan PJ, Meaney WJ, Fitzgerald JR, Deobald CF, Bohach GA, Smyth CJ 2005: Superantigen genes encoded by the egc cluster and SaPIbov are predominant among Staphylococcus aureus isolates from cows, goats, sheep, rabbits and poultry. J Med Microbiol 54: 401-411

Stephan R, Annemuller C, Hassan AA, Lammler C 2001: Characterization of enterotoxigenic Staphylococcus aureus strains isolated from bovine mastitis in north-east Switzerland. Vet Microbiol 78: 373-382

Strommenger B, Kettlitz C, Werner G, Witte W 2003: Multiplex PCR assay for simultaneous detection of nine clinically relevant antibiotic resistance genes in Staphylococcus aureus. J Clin Microbiol 41: 4089-4094

Sutra L, Poutrel B 1994: Virulence factors involved in the pathogenesis of bovine intramammary infections due to Staphylococcus aureus. J Med Microbiol 40: 79-89

Wang Y, Wu CM, Lu LM, Ren GW, Cao XY, Shen JZ 2008: Macrolide-lincosamide-resistant phenotypes and genotypes of Staphylococcus aureus isolated from bovine clinical mastitis. Vet Microbiol 130: 118-125

Werckenthin C, Cardoso M, Martel JL, Schwarz S 2001: Antimicrobial resistance in staphylococci from animals with particular reference to bovine Staphylococcus aureus, porcine Staphylococcus hyicus, and canine Staphylococcus intermedius. Vet Res 32: 341-362

Zong Y, Xu Y, Liang X, Keene DR, Hook A, Gurusiddappa S, Hook M, Narayana SV 2005: A 'Collagen Hug' model for Staphylococcus aureus CNA binding to collagen. Embo J 24: 4224-4236

Zschock M, Risse K, Sommerhauser J 2004: Occurrence and clonal relatedness of sec/tst-gene positive Staphylococcus aureus isolates of quartermilk samples of cows suffering from mastitis. Lett Appl Microbiol 38: $493-498$ 